\title{
Acta
Biochimica
Polonica
}

Vol. 47 No. 2/2000

$413-420$

QUARTERLY

\section{Comparative biochemical analysis of lectin and nuclease from Chelidonium majus $\mathrm{L}$.}

\author{
Ewa Fik ${ }^{1 凶}$, Michele Dalgalarrondo ${ }^{2}$, Thomas Haertlé ${ }^{2}$ and Anna Goździcka-Józefiak ${ }^{1}$ \\ ${ }^{1}$ Institute of Molecular Biology and Biotechnology, Międzychodzka 5, 60-371 Poznań, Poland \\ ${ }^{2}$ Groupe Protéines, Laboratoire d'Etude des Interactions des Molécules Alimentaires, Institut \\ National de la Recherche Agronomique, BP 71627, 44316-Nantes Cdx 03, France
}

Received: 8 March, 1999; revised: 18 October, 1999; accpted: 15 February, 2000

Key words: Chelidonium majus, glycosylation, plant lectins, glycoproteins

\begin{abstract}
It has been recently recognized that lectins exhibit other activities besides hemagglutination. Previously we have found that purified lectin from Chelidonium majus showed DNase activity (Fik, Goździcka-Józefiak \& Kędzia, 1995, Herba Polon. 41, 84-95). Comparison of lectin and DNase from the sap from leaves and roots of Chelidonium majus proved that both these compounds are composed of $24 \mathrm{kDa}$ monomer subunits which have an identical $\mathrm{N}$-terminal sequence but differ in amino-acid composition and degree of glycosylation. Possible interrelationship between lectin and DNase is discussed.
\end{abstract}

Lectins are carbohydrate binding proteins that are widely distributed among plants, animals and microbes [1]. Mature seeds are the main source of plant lectins, however, lectins are also present in small amounts in other tissues such as leaves and roots. The majority of plant lectins are secretory proteins that accumulate either in the vacuole or extracellular matrix [2]. Most plant tissues contain one lectin, but in some cases they, contain two (or more) lectins that differ in their biological properties [3-5].

Generally, lectins are glycoproteins consisting of subunits ranging in molecular mass from 25 to $35 \mathrm{kDa}$, arranged as dimers or tetramers, and existing as multiple isoforms sharing similar biochemical properties [6]. The subunits are usually identical or very similar, made up of single polypeptide chains that are encoded by different genes or by a family of closely related genes [7, 8]. In addition to their carbohydrate binding activity, some of the lectins such as those of hemagglutinin, galactosidase, polynucleotide adenosine glucosidase, or ribosome inactivating proteins show also other biological activities [9]. The lectin isolated from the sap of Chelidonium majus L. (further referred to as CM lectin) is

${ }^{{ }}$o whom correspondence should be addressed.

Abbreviations: CMD, DNase isolated from Chelidonium majus L.; CML, lectin isolated from Chelidonium majus L., i.d., inside dimension. 
associated with the other protein which exhibits DNase activity. Both proteins have oligomeric structure, each being composed of $24 \mathrm{kDa}$ monomer subunits differing in aminoacid composition charge and carbohydrate content [10]. CM lectin stimulates significantly proliferation of human lymphocytes, shows hemagglutination activity towards human erythrocytes of group B, has antimicrobial properties against multiresistant enterococci and staphylococci [11], and induces apoptosis in the CHO (Chinese hamster ovary) and epithelial cells of rat and mouse thymus cell lines [12]. The protein with DNase activity exhibit weak mitogenic and bacteriostatic effect $[11,12]$.

The aim of the present study was to explore the relation between lectin and DNase of Chelidonium majus.

\section{MATERIALS AND METHODS}

Plant material. Chelidonium majus plants were collected in the neighbour hood of Poznan during summer. The milky sap was isolated from leaves and roots of the plants and stored at $-70^{\circ} \mathrm{C}$ or $-20^{\circ} \mathrm{C}$ prior to being used.

Extraction and isolation of glycoproteins. Proteins were extracted from the yellow milky sap from leaves and roots of Chelidonium majus. The crude protein extract was prepared according to Diffey \& Stillman [13]. Protein fraction precipitated by ammonium sulphate (final concentration $0.8 \mathrm{M}$ ) was dissolved at $0.02 \mathrm{M}$ Tris/ $\mathrm{HCl}$ buffer containing $30 \%$ glycerol and was loaded on a Con A-Sepharose column equilibrated with $0.02 \mathrm{M}$ Tris/HCl buffer, $\mathrm{pH}$ 7.5, containing $0.5 \mathrm{M}$ $\mathrm{NaCl}$. The column was eluted with the same buffer and a linear gradient of 0 to $0.2 \mathrm{M}$ methyl- $\alpha$-D-glucopyranoside (methylglucoside) in the same buffer. Fractions of about $300 \mu \mathrm{l}$ were collected and the absorbance at $280 \mathrm{~nm}$, hemagglutination and DNase activity of all fractions were determined. The frac- tions showing lectin and DNase activity were pooled and proteins were precipitated with acetone. Protein concentration was determined according to Lowry et al. [14]. Purity of the separated proteins was checked by SDS/ PAGE according to Laemmli [15] and by RPHPLC.

Reverse phase HPLC (RP-HPLC). The HPLC equipment consisted of an auto-sampling injector model 231 (Gilson, France), with Millennium solvent delivery model 996 (Waters Associates, Milford, U.S.A.), a peak separator model 2150 and a fraction collector (ISCO, Lincoln, Nebraska, U.S.A.). The active fractions (CML and CMD) separated by affinity chromatography were digested by trypsin and pepsin and fractionated by RP-HPLC on a Nucleosil C-18 column (4 mm i.d. $\times 25 \mathrm{~cm}$ ) equilibrated with solvent A (0.11\% trifluoroacetic acid, $\mathrm{pH} 2.5)$. The elution was carried out for 40 min using a gradient from solvent A to solvent B $(80 \%$ acetonitrile, $20 \% \mathrm{H}_{2} \mathrm{O}, 0.09 \%$ trifluoroacetic acid). Both the column and the solvents were maintained at $40^{\circ} \mathrm{C}$. The flow rate was $0.6 \mathrm{ml} /$ min and the absorbance was recorded at $214 \mathrm{~nm}$. The fractions collected were dried in a Speed Vac Concentrator (Speed Vac Plus S.C. 110A (SAVANT)).

Hemagglutination assay. Assays for hemagglutination activity were performed as described by Kabat \& Mayer [16]. The aliquots contained in a final volume of $80 \mu \mathrm{l}: 50 \mu \mathrm{l}$ of $1 \mathrm{M} \mathrm{NaCl}$ and $0.5 \mathrm{mM} \mathrm{CaCl}_{2}$ in $0.05 \mathrm{M}$ Tris/HCl buffer, $\mathrm{pH} 7.5,25 \mu \mathrm{l}$ of the suspension of washed 3 times human erythrocytes (group $\mathrm{A}, \mathrm{AB}, \mathrm{B}, 0$ ), and $5 \mu \mathrm{g}$ of the lectin solution. After gentle mixing, the aliquots were incubated for $30 \mathrm{~min}$ at $37^{\circ} \mathrm{C}$ or for $24 \mathrm{~h}$ at $4^{\circ} \mathrm{C}$. Agglutination was monitored macroscopically.

DNase activity. DNase activity was assessed colorimetrically as described by Burton [17].

Amino-acid analysis. After acid hydrolysis under vacuum in $6 \mathrm{M} \mathrm{HCl}$ for $24 \mathrm{~h}$ at $110^{\circ} \mathrm{C}$ in Pico Tag Stations (Waters), amino acids were 
derivatized with PITC (phenylizothiocarbamyl aminoacid) according to Bidlingmeyer et $a l$. [18] and quantified by RP-HPLC on a Pico Tag C-18 column $(3.9 \mathrm{~mm}$ i.d. $\times 15 \mathrm{~cm}$, Waters).

Dried samples were dissolved in $95 \% 2 \mathrm{mM}$ $\mathrm{Na}_{2} \mathrm{HPO}_{4}, \mathrm{pH} 7.4$, containing $5 \%$ acetonitrile. The column was equilibrated with solvent $\mathrm{C}$ (0.14 $\mathrm{M} \mathrm{CH}_{3} \mathrm{COONa}$ in $6 \%$ acetonitrile containing $0.5 \mathrm{ml}$ TAE (Tris/acetate/EDTA buffer), $\mathrm{pH}$ 6.4, and eluted with a gradient from solvent $\mathrm{C}$ to solvent $\mathrm{D}\left(40 \% \mathrm{H}_{2} \mathrm{O}, 60 \%\right.$ acetonitrile). Both the column and the solvents were maintained at $38^{\circ} \mathrm{C}$. The flow rate was $1 \mathrm{ml} / \mathrm{min}$ and the absorbance was recorded at $254 \mathrm{~nm}$.

Deglycosylation of glycoproteins. Samples of glycoproteins were incubated successively with $1 \mathrm{M}$ and $2 \mathrm{M} \mathrm{HCl}$ for 1, 1.5, 3 and 4 $\mathrm{h}$ at $50^{\circ} \mathrm{C}$. The deglycosylated proteins were digested by trypsin and pepsin and the peptides were separated by RP-HPLC.

Amino-acid sequence determination. The $\mathrm{N}$-terminal sequence of amino acids was determined by Edman degradation with the Applied Biosystems 477A protein sequencer. Internal sequence were determined in proteins purified by RP-HPLC. The amino acid analysis was performed on Applied Biosystems 120A derivatizer, in which free amino acids were converted to phenyl thiohydantoin amino acids (PTH-amino acids), followed by separation on a PTH C-18 $185 \mu \mathrm{m}$ reverse phase column $(2.1 \mu \mathrm{m}$ i.d. $\times 220 \mathrm{~cm}$, Applied Biosystems) and detection at $254 \mathrm{~nm}$.

Staining of polyacrylamide gel. For detection of glycoproteins in polyacrylamide gel the carbohydrate-specific periodic acid Schiff (PAS) staining method was used as described by Carlson [19]. The whole incubation was performed by slow agitation at room temperature.

Isoelectric focusing (IEF). Isoelectric points of the lectin and DNase was measured using the LKB-2117 MULTIPHOR II (Bromma, Sweden). About 5-10 $\mu \mathrm{g}$ of protein was applied on the gel. The solution of $0.33 \%$ as- partic acid and $0.37 \%$ L-glutamic acid was added to the anode, and that containing $0.4 \%$ arginine and lysine to the cathode. Focusing was carried out in 5\% ultrathin layer of polyacrylamide gel Servalyt Precote (Serva), containing $2 \%$ ampholine, $\mathrm{pH} 3-10$, at $2{ }^{\circ} \mathrm{C}$ for $4 \mathrm{~h}$. The gel was then fixed in $20 \%$ trichloroacetic acid (TCA), stained with $0.1 \%$ Serva blue W in 5\% TCA, and destained in 1\% TCA.

Polyacrylamide gel electrophoresis. SDS/polyacrylamide gel electrophoresis and urea/polyacrylamide gel electrophoresis of glycoproteins was carried out according to Laemmli [15], using 10\% polyacrylamide as the separating gel and $5 \%$ polyacrylamide as the stacking gel. The proteins were reduced by heating at $100^{\circ} \mathrm{C}$ in the presence of 2-mercaptoethanol for $5 \mathrm{~min}$. Then, gels were calibrated using the following standard proteins: phosphorylase $b\left(M_{\mathrm{r}} 97000\right)$, bovine serum albumin ( $\left.M_{\mathrm{r}} 66000\right)$, ovalbumin $\left(M_{\mathrm{r}} 45000\right)$, carbonic anhydrase $\left(M_{\mathrm{r}} 29000\right)$ and $\alpha$-lactalbumin $\left(M_{\mathrm{r}}\right.$ 14200). Gels were fixed and stained with Coomassie blue R250.2. Alkaline urea/PAGE electrophoresis and electrophoresis under acidic conditions at $\mathrm{pH} 4.3$ were after Bollag \& Edelstein [20].

\section{RESULTS}

Isolation from Chelidonium majus L. sap of glycoproteins: lectin and DNase was achieved in two steps: ammonium sulphate fractionation of crude extract and affinity chromatography on Con A-Sepharose column as described by Fik et al. [10]. Purity of the two proteins in separated fractions was confirmed by SDS/PAGE (Fig. 1). Both activities were eluted in a single peak, but within its peak lectin and DNase were distinguished in separate fractions. Each yielded a single protein band of $24 \mathrm{kDa}$, whereas the molecular mass of native lectin and DNase eluted from Sephadex G-100 column was 164 and $84 \mathrm{kDa}$, respectively [10]. It is suggested that both pro- 
A

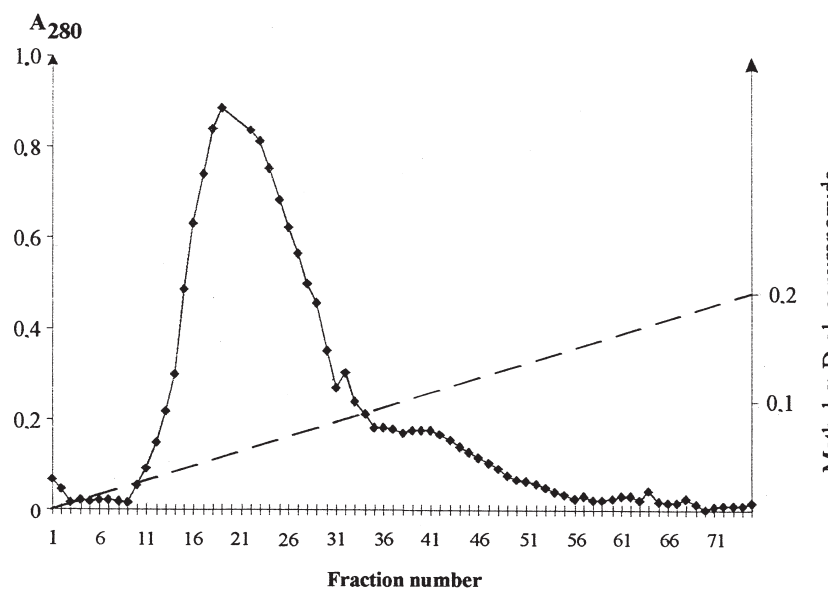

teins studied can be oligomeric forms composed of identical subunits of $24 \mathrm{kDa}$. Both proteins were glycosylated as confirmed by positive reaction with Schiff's reagent.

Analytical isoelectric focusing of lectin indicated the existence of different isoforms with pIs of, approximately, 7.4, 8.2 and 8.5. On the other hand, CMD migrated in the opposite direction and contained poorly focusing isoforms of $\mathrm{pH}$ about 5.8 (Fig. 2).

Urea/PAGE carried out at alkaline $\mathrm{pH}$ detects lectin and a very weak DNase band (Fig. $3 \mathrm{~A})$. In contrast, the same electrophoresis carried out at acidic $\mathrm{pH}$ with reversed electrode polarity (+ on the top), showed only the band of DNase (Fig. 3B). This is clearly indicative of opposite charges of the studied proteins at $\mathrm{pH}$ close to 7. HPLC elution profiles of lectin and DNase are similar, showing the same elution times and displaying three peaks (one major and two smaller) (Fig. 4). This might suggest that the native lectin and DNase are formed as different combinations of different subunits which have a similar molecular mass. The proteins present in the major peak (peak 3, Fig. 4) were used for amino-acid analysis.

This analysis (Table 1) showed that the subunits of the two proteins (lectin and DNase) differ in amino-acid composition sharing, however both, a high content of AsX, Ser, Thr, Val and Leu. Lectin is also rich in Gly and Phe, and DNase in Lys (Table 1). In spite of differences in amino-acid composition of the
Figure 1. A. Fractionation of protein extract from Chelidonium majus juice by affinity chromatography on Concanavalin A-Sepharose column.

Fractions 11-20: lectin; Fractions 21-27: DNase activity.

B $\begin{array}{lll}1 & 2 & 3\end{array}$

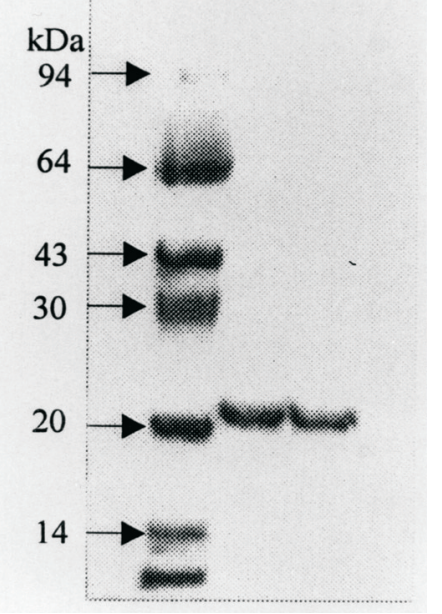

Figure 1B. SDS/PAGE of lectin and DNase after purification by affinity chromatography.

Lane 1, protein standards: phosphorylase $b$, bovine serum albumin, ovalbumnin, trypsin inhibitor and $\alpha$-lactalbumin; lane 2; lectin (fractions 10-20); lane 3; DNase (fractions 21-27).

two subunits, their N-terminal amino-acid sequence, as determined by Edman degradation of the first eighteen amino acids, is identical. It is as follows:

Ala-Asp-Thr-Ile-Val-Ala-Val-Glu-Leu-Asp-ThrTyr-Pro-Asn-Thr-Ser-Ile-Gly

This sequence shows high homology with that of lectin from Dioclea grandiflora L. from the family Fabaceae: 
Chelidonium majus L. lectin:

\section{ADTIVAVELDIYPNTSIG}

Dioclea grandiflora L. lectin: ADTIVAVELDSYPNTDIG [12].

\section{DISCUSSION}

Milky sap of Chelidonium majus is a very complex mixture of several biologically active substances such as alkaloids, carboxylic acids, amines and glycoproteins [10, 21, 22]. Two glycoproteins, one functioning as a good agglutination agent, a lectin, and another active as a nuclease termed DNase, were isolated and partially characterised [12]. Using thinlayer chromatoraphy for analysis composition of sugar after deglycosylation of each glycoprotein the sugars were separated and characterized. Sepharose, glucose, galactose and xylose were identified in lectin, and saccharose, glucose, arabinose and mannose - in DNase [10].

Probably, both glycoproteins are oligomers composed of $24 \mathrm{kDa}$ monomer subunits differing in amino acid, charge and carbohydrate content. However, as indicated by electrophoresis and isoelectric focusing, it might be that

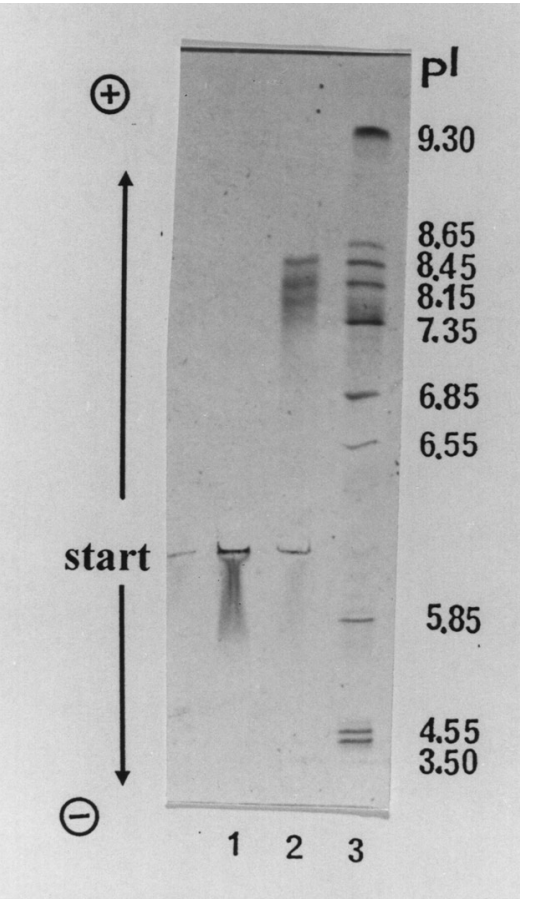

Figure 2. Isoelectric focusing patterns (pH 3-10 ampholine) of DNase (lane 1) and lectin (lane 2); gel calibration mixture (lane 3).

some subunits can be common to both these glycoproteins. Despite clearly detectable differences in charge between lectin and DNase, their hydrophobicity is similar as indicated by RP-HPLC.

Analysis of the N-terminal amino-acid sequence and amino-acid composition demonstrated that the dominant components of
A.

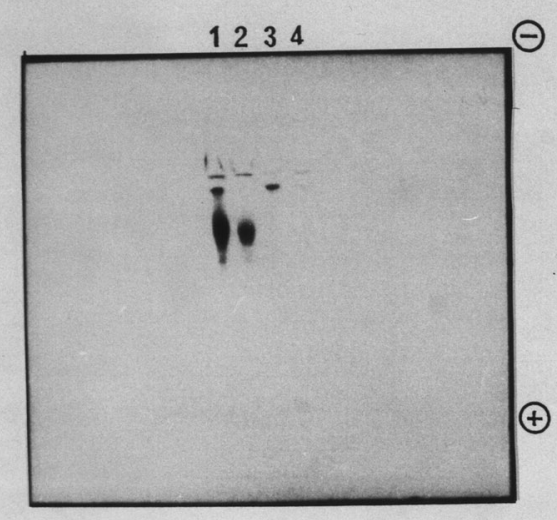

B.

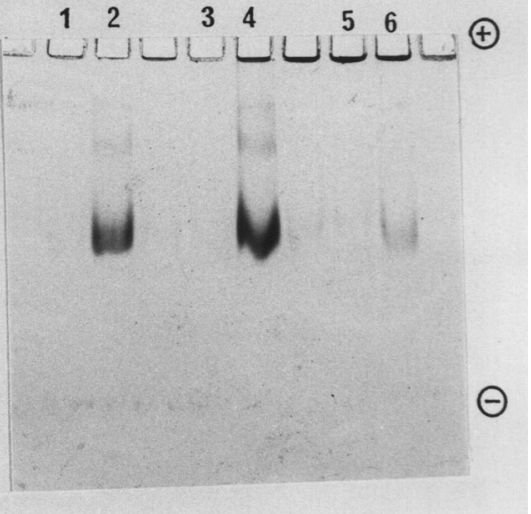

Figure 3. PAGE of lectin and DNase from Ch. majus at different pH.

A. Alkaline urea/PAGE at pH 8.8 of the unheated lectin, lanes 1 and 2, and DNase, lanes 3 and 4. B. PAGE in acidic conditions ( $\mathrm{pH}$ 3.5), with reversed electrode polarity ( + on the top). Lanes 1, 3, 5, lectin, lanes 2, 4 and 6, DNase. 
lectin and DNase could be products of distinct but related genes. Most of the known legume lectins are, in fact, encoded by a multigene ase resistance, quarternary structure as well as can modulate interaction of a glucoconjugate with other molecules [29]. There-

Table 1. Amino-acid composition of lectin and Dnase (\%) from Chelidonium majus

\begin{tabular}{lllllllllll}
\hline & Asx & Glx & Ser & Gly & His & Arg & Thr & Ala & Pro \\
\hline Lectin & 11.61 & 4.92 & 13.04 & 9.51 & 2.52 & 2.58 & 7.82 & 6.82 & 5.48 & 5.36 \\
DNase & 13.87 & 4.52 & 11.27 & 7.17 & 1.60 & 2.87 & 8.89 & 6.37 & Cys \\
\hline Lectin & 0.62 & 0.94 & 6.62 & 1.22 & 6.31 & 9.06 & 5.64 & 4.04 & 2.26 \\
DNase & 0.63 & 0.85 & 9.47 & 1.06 & 6.17 & 8.44 & 1.66 & 6.39 & 3.86 \\
\hline
\end{tabular}

family that arose by gene duplication and divergence from an ancestral gene [5, 23]. This family includes also the $\alpha$-amylase inhibitor, which plays an important role in plant defence against animals, and some storage proteins in legumes maize, potato and cereals [24].

In Sophora japonica bark there are five lectins which are formed by different combinations of two types of subunits. One subunit of the bark lectin and one subunit of the seed lectins, which are closely related proteins, are products of distinct genes [25]. Also lectins can appear as different molecular forms or isoforms produced by different genes. The occurrence of multiple isoforms of lectins can be explained by differences in the degree of their glycosylation and other modifications of subunits derived from a common precursor [26]. The differences observed between lectin and DNase from Chelidonium majus could have also resulted from differences in posttranslational processing of a common precursor.

This could be due either to differences in glycosylation or, as reported by Mandal et al. [27] and Young et al. [28] in the case of agglutinins from soybean and lentil peanut, to C-terminal proteolytic processing of subunits. Glycosylation plays an important role in biological function of native and recombinant glycoproteins. Oligosaccharides can modify intrinsic properties of proteins to which they are attached by altering their stability, prote- fore is possible that the difference in carbohydrate specificity between lectin and DNase decided about aggregation of each monomer of
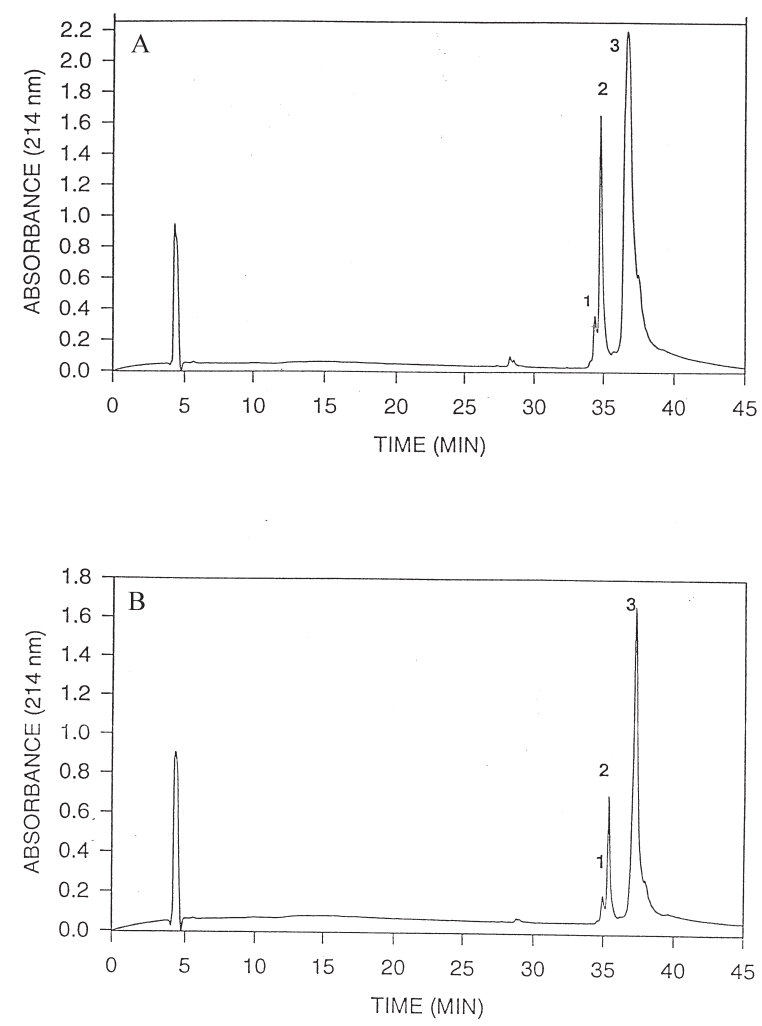

Figure 4. The elution profile from the RP-HPLC $\mathrm{C}_{18}$ column of the lectin and DNase from $\mathrm{Ch}$. majus purified by affinity chromatography.

A, lectin; B, DNase.

both proteins and also suggest that their association and dissociation may be accompanied 
by a change in conformation which is capable of modifying the catalytic sites of both proteins [30].

The proteins that display two types of activities: hemagglutination activity and enzymatic activity has been found previously in mung bean ( $\alpha$-galactosidase) and Vicia faba [7]. The mung bean protein can be reversibly converted by $\mathrm{pH}$ changes from tetrameric form, which possesses both enzymatic and hemagglutination activities to a monomeric form which possesses enzymatic activity only.

The course of evolution of plant lectins and of proteins associated with them has not been so far elucidated. Similarly, little is also known about their biological functions. It has been suggested that they play a role in plant defence against different pathogens and animals as well as in carbohydrate interactions $[10,12]$. Most of them might function as storage proteins.

The sequence of genes encoding the $\mathrm{kDa}$ subunit proteins would provide an answer on their interesting interrelationship.

\section{R E F E R E N C E S}

1. Sharon, N. \& Lis, H. (1990) Legume lectins - a large family of homologous proteins. FASEB J. 4, 3198-3208.

2. Lis, H. \& Sharon, N. (1981) Lectins in higher plants; in Biochemistry of Plants, vol. 6, Proteins and Nucleic Acids, pp. 371-466, Academic Press Inc. New York.

3. Tazaki, K. \& Yoshida, K. (1992) The bark lectins of Robinia pseudoacacia: Purification and partial characterisation. Plant Cell Physiol. 33, 125-129.

4. Etzler, M.E. (1994) Isolation and characterisation of subunits of DB58, a lectin from the stems and leaves of Dolichos biflorus. Biochemistry 33, 9778-9783.
5. Van Damme, E.J.M., Goldstein, I.J., Vercammen, G., Vuylsteke, J. \& Peumans, W.J. (1992) Lectins of member of the Amarylidaceae are encoded by multigene families which show extensive homology. Physiol. Plant. 86, $245-252$.

6. Etzler, M.E. (1985) Plant lectins: Molecular and biological aspects. Annu. Rev. Plant Physiol. 36, 209-234.

7. Van Damme, E.J.M., Barre, A., Smeets, K., Tarrekens, S., Van Leuven, F., Ruuge, P. \& Peumans, W.J. (1995) The bark of Robinia pseudoacacia contains a complex mixture of lectins. Plant Physiol. 107, 833-843.

8. Yoshida, K., Baba, K. \& Tazaki, K. (1994) Cloning of a lectin cDNA and seasonal changes in levels of the lectin and its mRNA in the inner bark of Robinia pseudoacacia. Plant Mol. Biol. 25, 845-853.

9. Battelli, M.G., Baribieri, L., Bolognesi, A., Buanamici, L., Valbonesi, P., Polito, L., Van Damme, E.J.M., Peumans, W.J. \& Stripe, F. (1997) Ribosome inactivating lectins with polynucleotide: Adenosine glucosidase activity. FEBS Lett. 408, 355-359.

10. Fik, E., Goździcka-Józefiak, A. \& Kędzia, H. (1995) Isolation and characterization of glycoproteins from milky juice leaves and roots of Chelidonium majus. Herba Polon. 41, 84-95.

11. Fik, E., Goździcka-Józefiak, A., Mirska, I. \& Kędzia, W. (1997) New plant glycoprotein against methicillin resistant Staphylococci and Enterococci. Acta Microb. Pol. 46, 325-327.

12. Fik, E., Skonieczna, D., Dobruchowska, A., Poręba, E., Goździcka-Józefiak, A. \& Kędzia, H. (1996) Effect of Chelidonium majus glycoproteins on lymphocytes transformation from women suffering from cervical cancer. Herba Polon. 42, 276-281.

13. Diffey, J.P. \& Stillman, B. (1988) Purification of a yeast protein that binds to origins of DNA 
replication and transcriptional silencer. Proc. Natl. Acad. Sci. U.S.A. 85, 2120-2124.

14. Lowry, O.H., Rosebrough, N.J., Farr, A.L. \& Randall, R.J. (1951) Protein measurement with the Folin phenol reagent. J. Biol. Chem. 193, 265-275.

15. Laemmli, U.K. (1970) Cleavage of structural proteins during assembly of the head of bacteriophage T4. Nature 227, 680-685.

16. Kabat, E.A. \& Mayer, M.M. (1961) in Experimental Immunochemistry (Thomas, Ch.C., ed.) 2 edn., pp. 123-125, Springfield.

17. Burton, K. (1956) A study of the conditions and mechanisms of the diphenylamine reaction for the colorimetric reaction of deoxyribonucleic acid. Biochemistry 62, 314-322.

18. Bidlingmeyer, B.A., Cohen, S.A. \& Tarvin, T.L. (1984) Rapid analysis of amino acids using pre-column derivatization. J. Chromatogr. 336, 93-94.

19. Carlson, S.R. (1988) Isolation and characterisation of glycoproteins; in Glycobiology. A Practical Approach (Fukuda, M. \& Kobata, A., eds.) pp. 14-16, ORL Press, Oxford, New York, Tokyo.

20. Bollag, D.M. \& Edelstein, S.J. (1991) Gel electrophoresis under denaturing conditions; in Protein Methods, pp. 95-143, A John Wiley \& Sons. INC., Publication, Wiley-Liss, New York.

21. Sambrook, J., Fritsch, E.F. \& Maniatis, T. (1989) Molecular Cloning. A Laboratory Manual, 2 edn., Cold Spring Harbor Laboratory Press.

22. Collombo, M.L. \& Boisisio, E. (1996) Pharmacological activities of Chelidonium majus $\mathrm{L}$. (Papaveraceae). Pharm. Res. 33, 127-134.
23. Goździcka-Jozefiak, A., Kędzia, H. \& Poreba, E. (1992) Properties of proteins contained in milky juice from Chelidonium majus. Herba Polon. 38, 183-187.

24. Van Damme, E.J.M., Smeets, K., Torrekens, S., Van Leuven, F., Goldstein, I.J. \& Peumans, W.J. (1992) The closely related homomeric and heteromeric mannose-binding lectins from garlic are encoded by one-domain and two-domain lectins genes, respectively. Eur. J. Biochem. 206, 413-420.

25. Peumans, W.J. \& Van Damme, E.J.M. (1995) Lectins as plant defence proteins. Plant Physiol. 109, 347-352.

26. Ueno, M., Ogawa, H., Masumoto, I. \& Seno, N. (1991) A novel mannose-specific and sugar specifically aggregatable lectin from the bark of the Japanese pagoda tree (Sophora japonica). J. Biol. Chem. 266, 3146-3153.

27. Mandal, D.K., Nieves, E., Battacharya, L., Orr, G.A., Roboz, J., Yu, Q. \& Brewer, C.F. (1994) Purification and characterisation of three isolectins of soybean agglutinin. Evidence for C-terminal truncation by electrospray ionisation mass spectrometry. Eur. J. Biochem. 221, 547-553.

28. Young, M.N., Watson, D.C. \& Thibault, P. (1996) Post-translational proteolytic processing and the isolectins of lentil and other Vicae lectins. Glycoconjugate J. 13, 575-583.

29. Weis, W.J. \& Drickamer, K. (1996) Structural basis of lectin carbohydrate recognition. Annu. Rev. Biochem. 65, 441-473.

30.Joao, H.C. \& Dwek, R.A. (1993) Effects of glycosylation on protein structure and dynamics in ribonuclease $B$ and some of its individual glycoforms. Eur. J. Biochem. 218, 239-244. 